\title{
The Arab Spring: A New Era of Humor Consumption and Production
}

\author{
Wafa Abu Hatab ${ }^{1}$ \\ ${ }^{1}$ Department of English Language and Literature, Zarqa University, Jordan \\ Correspondence: Wafa Abu Hatab, Department of English Language and Literature, Zarqa University, Jordan. \\ E-mail: whatab@zu.edu.jo
}

Received: March 7, 2016 Accepted: May 5, 2016 Online Published: May 25, 2016

doi:10.5539/ijel.v6n3p70 URL: http://dx.doi.org/10.5539/ijel.v6n3p70

\begin{abstract}
The 26-year-old Tunisian street vendor, Mohammad Bouazizi set himself ablaze, sparking demonstrations and revolutions in more than one country in the Arab world. Protestors utilized all possible forms of expression to give an outlet for the long suppressed feelings, attitudes and thoughts. A new social discourse emerged where freedom of expression was imposed. Tunisia led the move and was followed by Egypt, Libya, Yemen and Syria. Though these revolting countries have many things in common, each has its own touch to the mosaic portrait of the new social discourse. Political satire has its place in this discourse where political humor has witnessed a tremendous boom. The present study was based on data obtained from cartoons, slogans, digital discourse and jokes. It investigated the use of humor by protesters in the Arab Spring countries, the linguistic devices employed and the role of intertextuality. The study revealed that humor was used in the Arab Spring countries to denigrate the presidents. Sources for intertextuality included proverbs, songs, poetry and commercials. Humor made use of some linguistic devices such as puns, synonyms, antonyms, lexical ambiguity and rhyme.
\end{abstract}

Keywords: Arab Spring, humor, intertextuality, ambiguity, hegemonic discourse

\section{Introduction}

Humor is a significant aspect of social interaction that has been part of the behavioral repertoire of human beings for thousands of years. Ancient Greek texts contain descriptions of "professional" jesters and joke books (Bremmer, 1997, pp. 11-18). One of the earliest historical figures associated with humor and laughter was the Greek philosopher Democritus who was known as the "laughing philosopher".

Since the spring of 2011, a wave of discontent regarding authoritarian regimes has swept across the Middle East and North Africa, where humorous discourse has been mocking the existing rules. Making fun of oneself or of a discourse becomes successful when it touches the elements that constitute the rule-driven existence of this discourse and makes it meaningful at the center of popular attention. Political humor looks with eagle eyes at the minute details and spotlights them so the myth of the regime is distorted and its collapse starts. Humor and political satire turn the world upside-down, challenging the power relations as part of the popular cultural aim to resist, revealing a counter-hegemonic discourse. It has always been used in many Arab countries even before the sudden outbreak of the Arab Spring. Countries such as Tunisia, Egypt, Yemen and Syria faced their tyrannical leaders with a remarkable courage combined with patience and determination.

While a lot of academic attention has been paid to the roots of the Arab Spring revolutions, the role of humor in these rebellions has not been investigated. The present study investigated the way political humor was employed as a means of resistance, a weapon against the regime's oppression that facilitated its breakdown focusing on the portrayal of three Arab leaders and addressing the following questions:

1) What types of humor have been used by protestors in the Arab Spring countries?

2) How does intertextuality contribute to political humor in the Arab Spring protests?

3) What are the linguistic devices through which humor and intertextuality manifest themselves?

\section{Theoretical Background}

Humor theories date back to Plato who tackled the effect of laughter rather than humor. (Provine, 2000, pp. 12-13). Michael Mulkay (1988) viewes humor as one of the modes people use in communication classifying mode into serious and humorous. While the serious mode is characterized by consistency, coherence, and avoidance of ambiguity, humorous mode violates these principles to cope up with contradictions caused by the 
complex real world. Mulkay (1988) defines humor as a way for people to deal with these contradictions in their communication so as to negotiate difficult interpersonal situations.

The word "humor" itself is of a relatively recent origin. According to the Oxford English Dictionary, it arose during the 17th century. Humor can be considered as an interdisciplinary topic that has been tackled by linguists, psychologists as well as sociologists, which led to its "epistemological hairsplitting" (Attardo, 1994, p. 1). Lack of a precise definition of humor might be attributed to the problems of the terminology used to describe it. Linguists, psychologists and anthropologists have taken humor to be an all-encompassing category covering any event or object that elicits laughter, amuses or felt to be funny.

Each discipline approaches humor studies differently. Psychology, for example, tackles the indifferent manifestations of humor. The definition of what humor is ultimately depends on the purpose for which it is used. As Attardo (1994, p. 4) points out, in the field of literary criticism, for example, there is a need for a fine-grained categorization, whereas linguists have often been happy with broader definitions, arguing that whatever evokes laughter or is felt to be funny is humor, i.e. that humor can be deduced from its effect. However, laughter as such is not necessarily a condition for humor. Some definitions of humor focus on the pragmatic effect of humor where humor is viewed as a text whose perlocutionary, i.e., intended, effect is laughter.

Plato is considered to be the first theorist of humor. According to Plato, humor is "a mixed feeling of the soul". Piddington (1933, p. 152). Humor theories can be classified into incongruity, superiority, and relief theories. Incongruity theory includes historical figures such as Immanuel Kant (LaFollette \& Shanks, 1993), Norman Maier (Vaid, 1999), Arthur Schopenhauer (Province, 2000). The main focus of this school is the object of humor which is seen as a response to an incongruity, a term broadly used to include ambiguity, logical impossibility, irrelevance, and inappropriateness.(Attardo \& Raskin 1991; Attardo 1994, 2001) provide a linguistic framework for this theory in which incongruity involves opposition between two scripts, where a script is defined as a cognitive structure involving the semantic information associated with the words included in a text, representing a speaker's knowledge of the world, and providing information on the structure, components, functions, etc. of the entity or activity referred to. Humor results from the violation of what is expected or considered normal in given circumstances.

Superiority theory can be traced back to Plato and Aristotle (Morreall, 1983, 1987).The central idea of superiority theory is that humor may involve aggression, disparagement, or criticism, or hostility that emphasizes the producer's negative attitude and feeling of superiority to some person or group, typically on political, ethnic or gender grounds. Studies that adopt such a theory are Keith-Spiegel (1972), Morreall (1983), (1987); Raskin (1985), Attardo (1994) and Billig (2005).

Relief theory is typically associated with Sigmund Freud, who views humor as an outlet for feelings of repression. The psychological effect of humor on the recipient is the central focus of this theory where humor is considered as a "substitution mechanisms". Freud (1905/1991, p. 145) argues that "the repressive activity of civilization brings it about that primary possibilities of enjoyment, which have now, however, been repudiated by the censorship in us, are lost to us". Hence, during the process of civilization, the expressions of human hostility and aggressiveness have been reduced to the level of tendentious humor. Studies adopting this view are Mulkay (1988) and Bippus (2007).

\section{Review of Related Literature}

Linguistic theories of humor are introduced by Raskin (1985) where verbal humor in punch line jokes is investigated. Attardo (1994) presents an overview of the linguistic theories of humor classifying them into: Structuralist, semiotic, sociolinguistic, and script-based theories. Structuralists approach is adopted by Greimas's (1966, 1970) applying the concept of isotopy that is derived from the polysemous constituents of the text.

Semiotic theories were introduced by Koestler's (1964) cognitive bisociation model. Bisociation model is defined by Koestler as "the perceiving of a situation or idea [--] in two self-consistent but habitually incompatible frames of reference" (1964, p. 35, as cited in Attardo 1994, p. 175).

(Attardo, 1994, p. 177) and Eco (1986) integrate pragmatic competence that involves conversational implicature and intertextuality (Attardo, 1994, p. 180) into humor research. Both researchers applied Grice's Cooperative Principle to humor research (Attardo, 1994, p. 272).

The sociolinguistic approach to humor makes use of conversational analysis. Sacks (1972) and Sherzer (1978) explored conversational puns.

Generative grammar was the base for Script-based theories of humor led by Raskin (1985, p. 81) who postulates that "a text can be characterized as a single-joke-carrying text if both of the (following) conditions [--] are 
satisfied [:] i) The text is compatible, fully or in part, with two different scripts [and] ii) The two scripts with which the text is compatible are opposite [--]". A script is defined as "a large chunk of semantic information surrounding the word or evoked by it" (Raskin, 1985, p. 81), i.e., all the information, both intralinguistic and extralinguistic, or encyclopedic, included in a lexical unit (Attardo, 1994, p. 201). Scripts are linked with other scripts, forming "semantic networks" (Attardo, 1994, p. 201).

Rhodes (2013) tackled discourse of Arab Spring focusing on the contextual factors and their influence on the discourse employed in the 2011 and 2013 uprisings in Egypt and Tunisia. The basic objective of that study was to find out how the Arab Spring had affected people's life.

Abu Hatab (2013) investigated the changing identities in the political speeches of four Arab Spring countries former presidents tracing how different identities of these leaders were established and analyzing the linguistic resources utilized to establish them. The study revealed that there was a drastic move from the semi-god leader to that one that was dying to seek people's understanding and support. That change was reflected basically through the use of personal pronouns, lexical repetition and use of colloquial Arabic.

Lahlali (2011) tackled the themes and structures of the last three speeches by President Hosni Mubarak of Egypt and President Zine El Abidine Ben Ali of Tunisia before they were forced out of office focusing on their linguistic strategies.

The fact that Arabic humor has always coped up with social, historical as well as political transformations contributed to its flexibility and comprehensiveness. No matter where or when humor is used in the Arab world, it is not difficult to comprehend and appreciate. It has always been utilized as a safety- valve when people feel overloaded with fear and anxieties of new realities in their attempt to preserve their identity. Through humor and the pleasure of laughter we approach aspects of the regime that seem inaccessible and covered by censorship. Humor is one persuasive communication technique that may be used to stimulate positive feelings towards the source of the humorous comments through the audience's laughter. In the case of humorous attacks on opponents, laughter eliciting humor may strengthen mutual bonds while at the same time opening distance between the audience and the targeted opponent.

Studying this social phenomenon across different eras of Arab history shows that the Arabs' tendency to resort to humor as a self defense mechanism increases during critical times in an attempt to save social and human existence to keep away from the jungles of frustration and hopelessness.

The Functions of political humor vary according to users and addressees. Politicians might employ it to achieve political gains while the public have their various reasons. Usually, when hostility to a political leader increases, political humor is geared towards distorting his image. Orwell referred to political jokes as "tiny revolutions." Use of humor is sometimes viewed as a violation of the social norm in a response to a deep desire "to violate, but without risk" (Eco, 1986, p. 271). Humor is then seen as "a violation of a rule," (Eco, 1986, p. 270).

\section{Method}

A random sample of slogans and cartoons used by protesters in four Arab Spring countries was collected during February and March 2012. It included slogans used by protesters in Egypt, Syria, Yemen and Tunisia. Humorous expressions in these slogans were identified and classified adopting Raskin's (1985) taxonomy of political humor. Sources of intertextuality and the linguistic devices employed were then outlined. Raskin (1985, p. 222-246) classifies political jokes into denigration jokes and exposure jokes. Scripts representing the first class involve:

Denigration of a Political Figure, showing him as stupid, indecent unpopular, hated, Denigration of a Political Group or Institution and Denigration of a Political Idea or Slogan, Exposure joke, on the other hand,involve exposure of national trait, exposure of political repression, exposure of shortages and exposure of specific political situations.

\section{Analysis and Discussion}

\subsection{Denigration of a Political Figure}

Denigration of a political figure is achieved by showing him as stupid, indecent, unpopular or hated. The following slogans represent denigration $f$ Mubarak being shown as unpopular and hated. The second slogan in the first row is simply translated as "get lost" followed by another one in the following row which says "If you don't want to go to Jeddah, there is Riyadh and Dammam or even China, China is beautiful". 


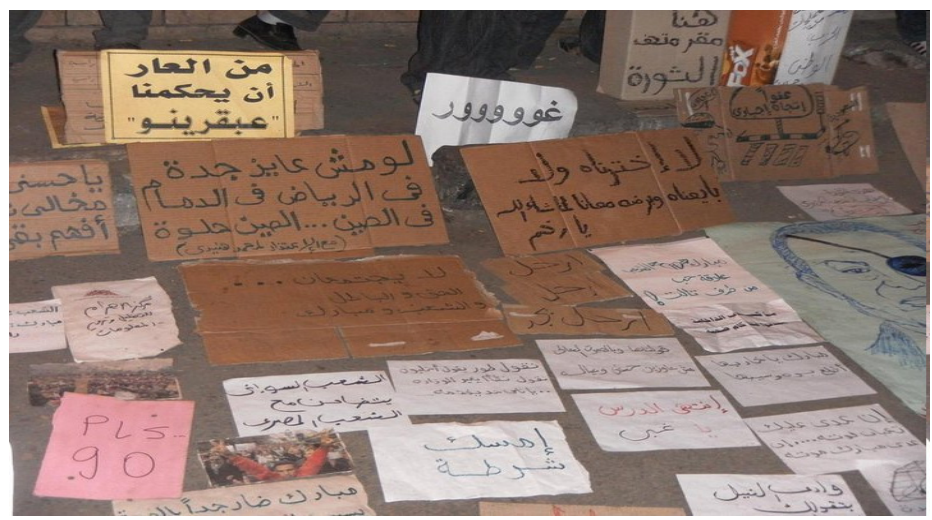

5.1 .1

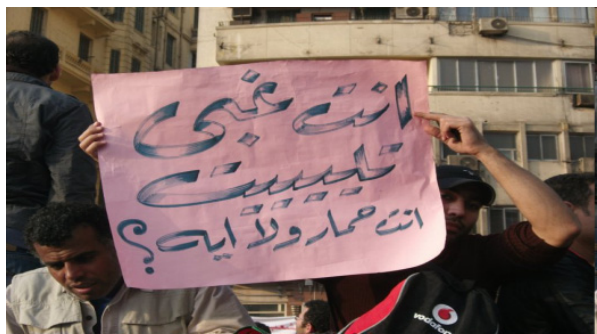

5.1 .2

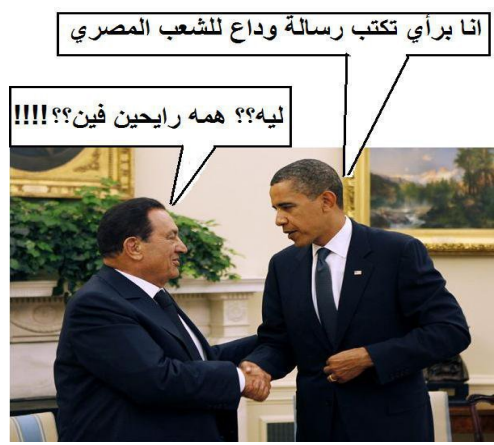

5.1 .3

The slogans in the above examples address Mubarak accusing him of stupidity, (5.1.2) says "Are you stupid...or Are you a donkey?" The word "donkey" is used to intensify stupidity as a trait given to Mubarak. It is quite common to compare a stupid person to a donkey in colloquial Arabic. Obama advises Mubarak to write a farewell letter to his nation and Mubarak asks, "Why? Where are they going?"

In the following examples, denigration of Mubarak is achieved by showing how unpopular he had become. In example (5.1.4) a child carries a slogan saying "Even children do not want you to stay". The hatred is even shared by the unborn as portrayed by the slogan in example (5.1.5) where a man carries a slogan saying "Leave, my wife wants to give birth and the baby does not want to see you". The implicature here is that even the unborn hate Mubarak to the extent that they decide not to come to life until Mubarak leaves. Mubarak's presence is shown as a thorn in the flesh for both the pregnant mother and her baby who is stuck inside waiting for Mubarak to leave.

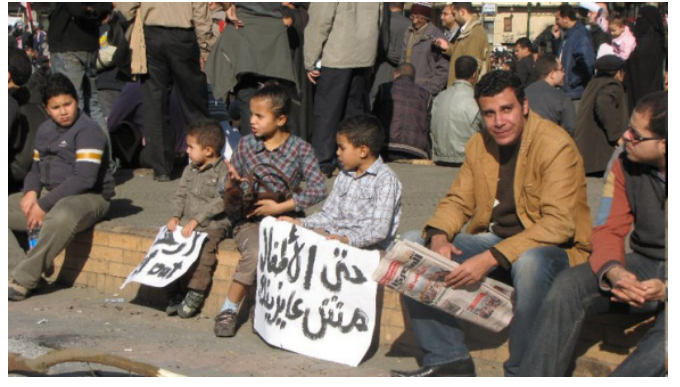

5.1 .4

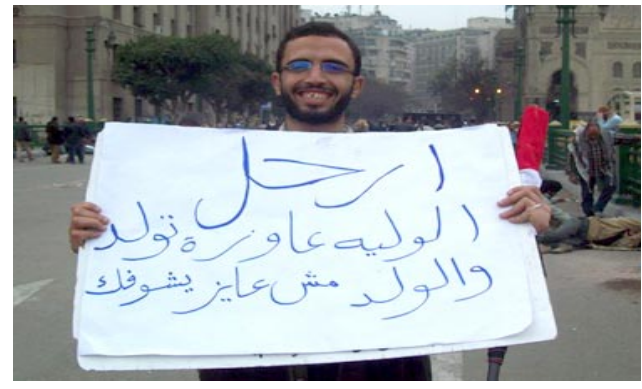

5.1 .5 
In the following example, the word "ارحل"," "leave" is written upside down to denigrate Mubarak stressing his abnormal character. The comment under the word reads, "He might understand it when it is written upside down, how can I explain it to you, you tired me off". In example (5.1.7) the hatred of Mubarak reaches its climax calling him a devil. The slogan literally says "Get lost, I seek refuge in God from the Satan".

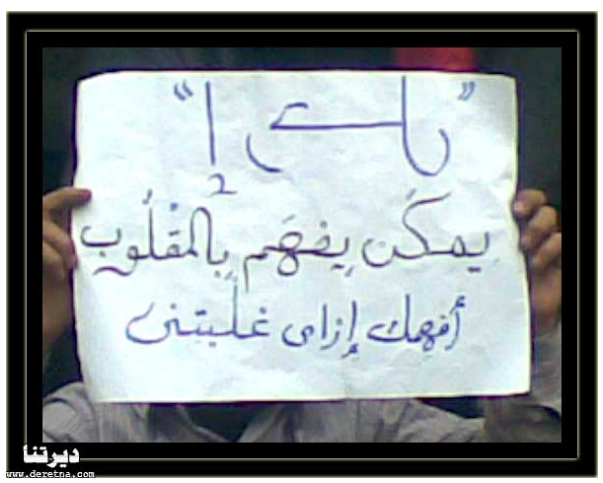

5.1 .6

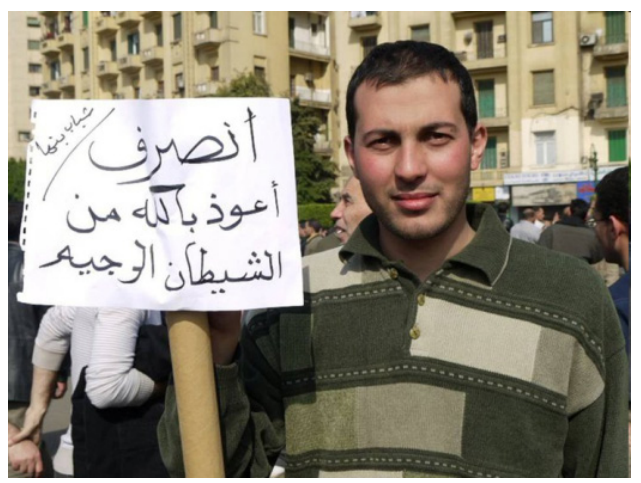

5.1 .7

In example (5.1.8), Mubarak is presented as an indecent person, a criminal to the extent that the writer appeals to Bin Laden to send him a friend request. Such a phrase could be an implication of the writer's wishful thinking for Mubarak to have the same end of Bin Laden. It is written in English, though Bin Laden was an Arab, to reveal the negative traits of Mubarak to the world not only the Arabs.

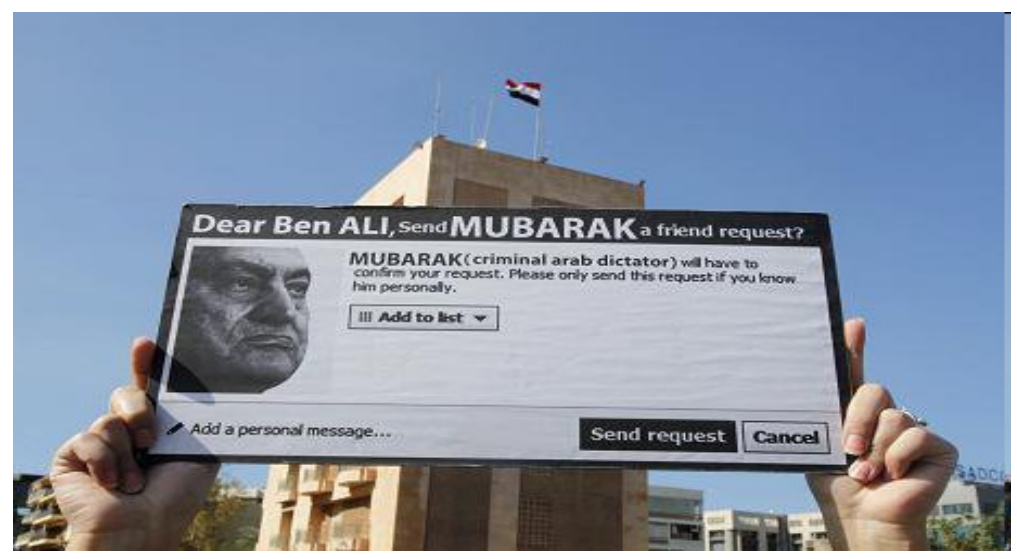

5.1 .8

Denigration of Arab Spring dictators also took the form of commenting on their linguistic behavior. The Syrian president is said to be a lisper pronouncing the sound $/ \mathrm{s} /$ as $/ \theta /$. In the following slogan (5.1.9), he is addressed by his first name being mocked for this difficulty. The protesters told him that they would not stop even if he could pronounce the $/ \theta /$ as $/ \mathrm{s} /$. They imitate his pronunciation replacing $/ \mathrm{s} /$ in the word "mundassin" by $/ \theta /$ writing it as "munda $\theta$ in". 


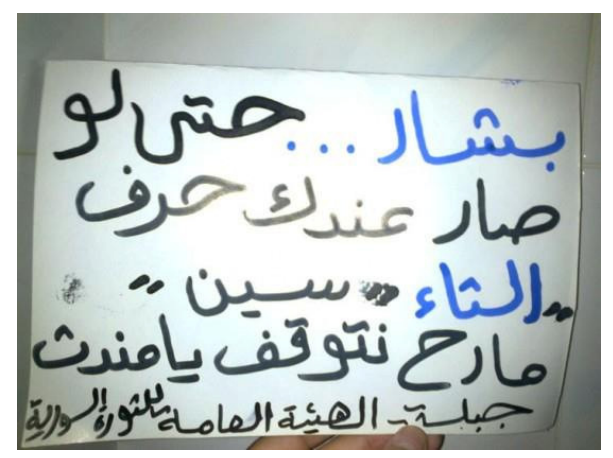

5.1 .9

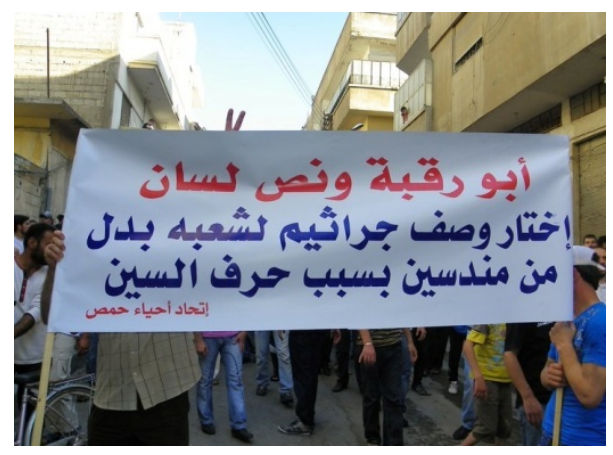

5.1 .10

The slogan in (5.1.10) denigrates Asad who is given an epithet "the one with a tall knick and half a tongue". No names are given, just a negative epithet. That was a response to Asad calling the Syrians جر اثيم "germs" rather than منسسين to avoid the pronunciation difficulty.

Denigration of Asad and his regime is also manifested in the following example where the regime is compared to a bull in a bull fight.

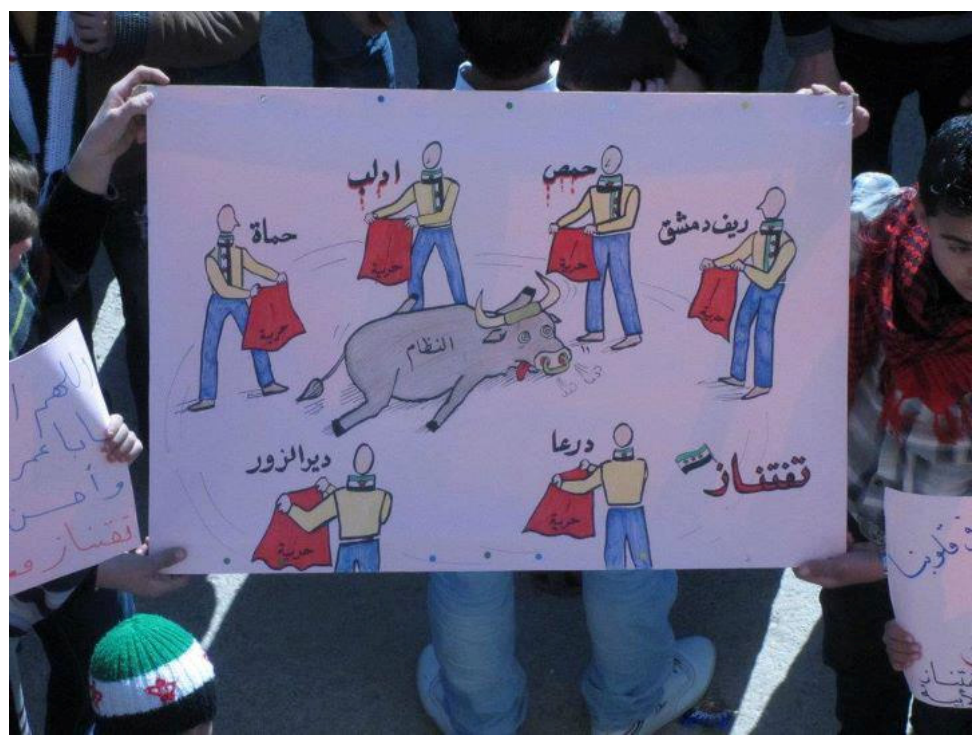

5.1 .11

\subsection{Denigration of a Political Group or Institution}

The second category of denigration jokes proposed by Raskin (1985) is denigration of a political group or institution. Cartoon (5.2.1) shows the Tunisian president already been kicked out of the political arena while the Yemeni president Saleh and the Egyptian, Mubarak are trying to escape their fate each suggesting that the other should jump first. The three leaders' continuous appearance together motivated many Arabs to think of them as one political group. 


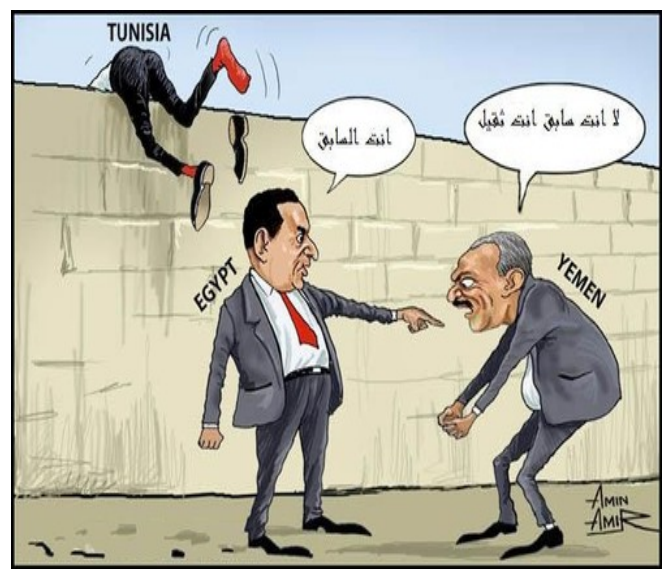

5.2 .1

In the following slogan humor derives from denigration the political institution that aims at scarifying all to save its name. This slogan could be literally translated as "Baba Nwail (Santa Claus) was arrested because his name is similar to Baba Amr."

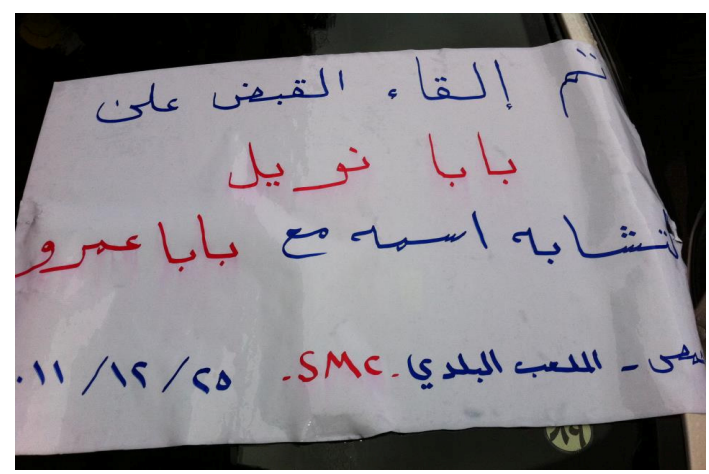

5.2 .2

The whole political institution that Mubarak leads is made fun of in the following slogan. All ministers in his government are denigrated by establishing a comparison between their family names which carry positive connotations and their real political performance which totally contradicts these names. Minster of Education's names is "Thaki" which means "smart" while students are "stupid". This indicates the total failure of this minister in his job. Minister of finance family name is "Ghali" which means "precious", while the whole nation is "cheap". Humor here derives from the contradiction between the family name "Ghali" and the situation of people, they are very poor. Minster of interior's name is "al?adli", "the just" while the whole nation is treated "unjustly". Prime minister's family name is "Nathif" and pollution is killing people. Parliament head is called "Sorur", "happiness" and people are overwhelmed by grief.

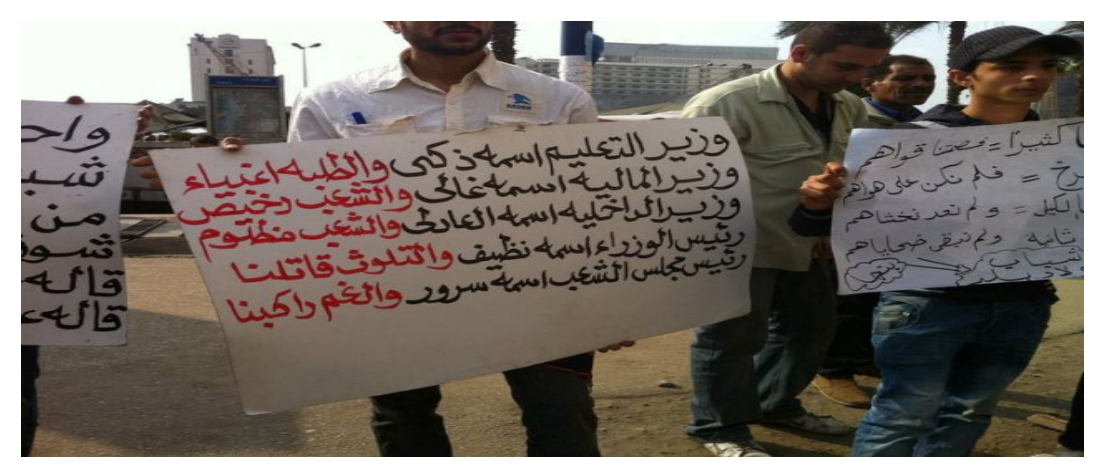




\subsection{Denigration of a Political Idea or Slogan}

Such a class involves making fun of a political idea or a slogan used by a political figure or group. In the following example, the idea of the current Secretary-General of the United Nations Ban Ki- moon visiting Syria to interfere is made fun of since such a visit is viewed as a waste of time with a regime that shows total ignorance to such visit. The following slogan says, "Ban Ki- moon, is calling, a missed call, reject, options".

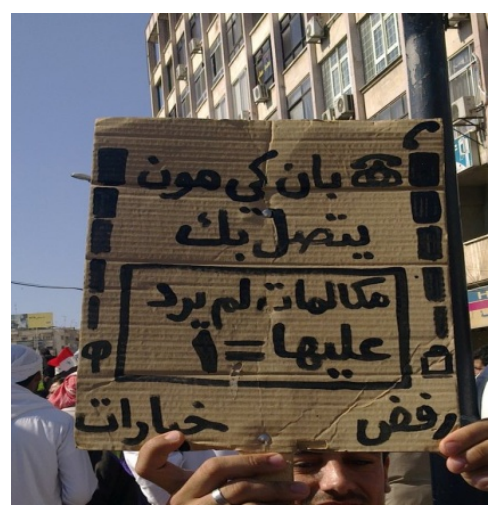

5.3.1

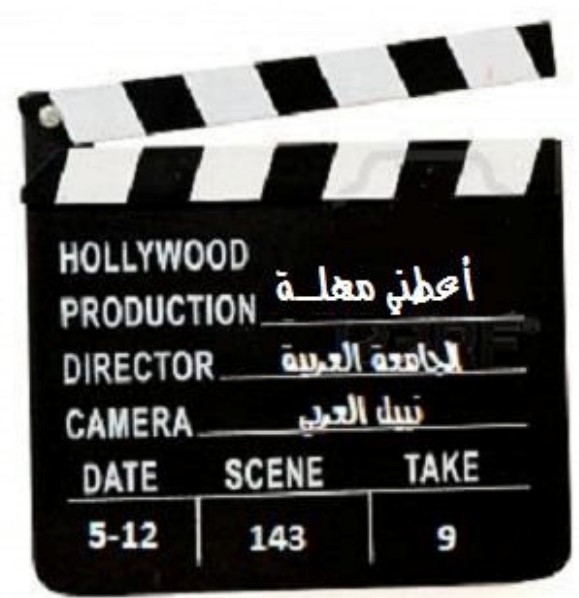

5.3.2

In (5.3.2) the idea of the Arab League interference in Syria is denigrated and shown as a scene of a Hollywood movie. The scene is entitled "Give me a break" directed by the Secretary-General of the League of Arab States Nabil Elaraby. The scene is given the number 143.

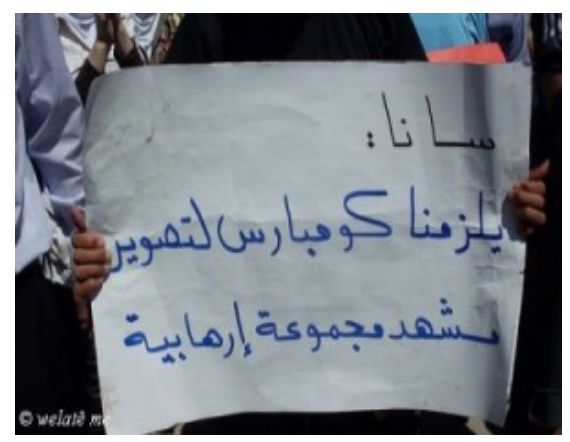

5.3 .3 
The above slogan makes fun of Sana's comment that the Syrian protests are led by terrorists. It reads, "We need extras to act a terrorist group scene". The idea that the Syrian regime tried to market regarding external forces behind the Syrian protests is highlighted in the following slogan which reads, "This demonstration is sponsored by unknown external parties".

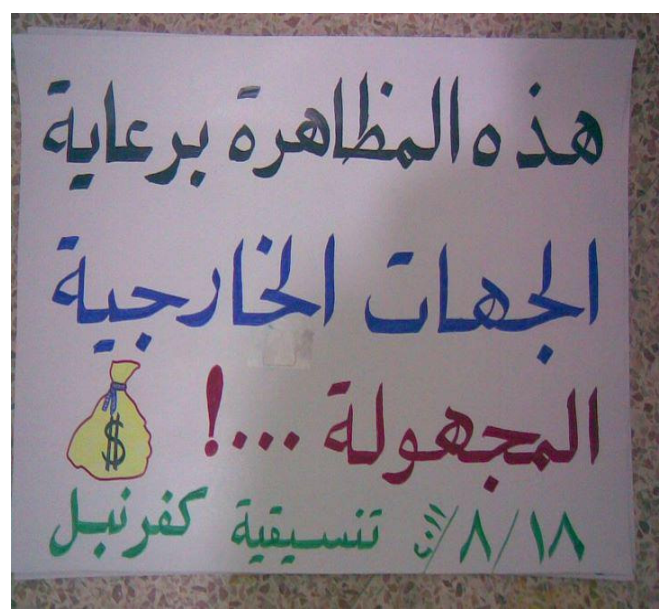

\subsection{4}

Humor can also derive from ridiculing the idea that any explosion is caused by a-Qaeda. It says, "In ten minutes, investigation revealed that al-Qaeda is behind the two explosions, it takes half an hour for urine analyses". The implicature here is that the regime issues judgments in serious issues hastily and irrationally. If it takes half an hour for urine analysis results to be out, how come that investigation of a serious issue is done in 10 minutes?

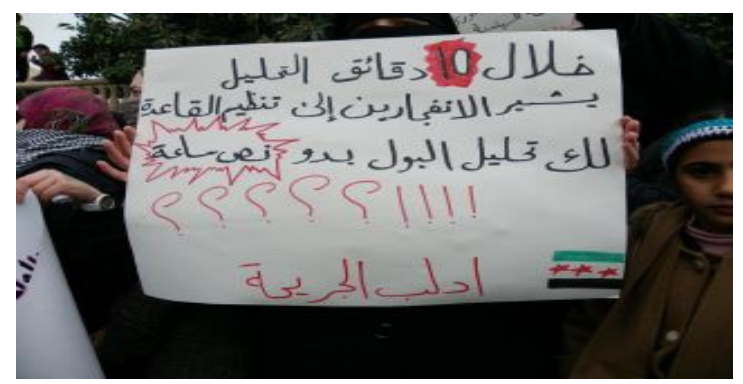

5.3.5

\subsection{Exposure Jokes}

This category deals with exposure of political repression (terror and arrests, the lack of political freedom and civil liberties, viz. freedom of speech), exposure of shortages (and exposure of specific political situations (understanding them often presupposes specific encyclopedic knowledge about certain historical events, peculiarities of specific political regimes, etc.) (Raskin, 1985).

Exposure of terror is manifested in the following slogans, the first calls for carrying a slogan and getting one bullet for free from the security forces. The second example demonstrates the extent to which terror is practiced against protestors in Syria. Emergency call numbers are given, not to aid people but to punish them brutally. The slogan reads "we receive citizens' complaints on the following numbers, 115: extracting a larynx, 119: taking eyes off, 111: cutting hands or legs". 


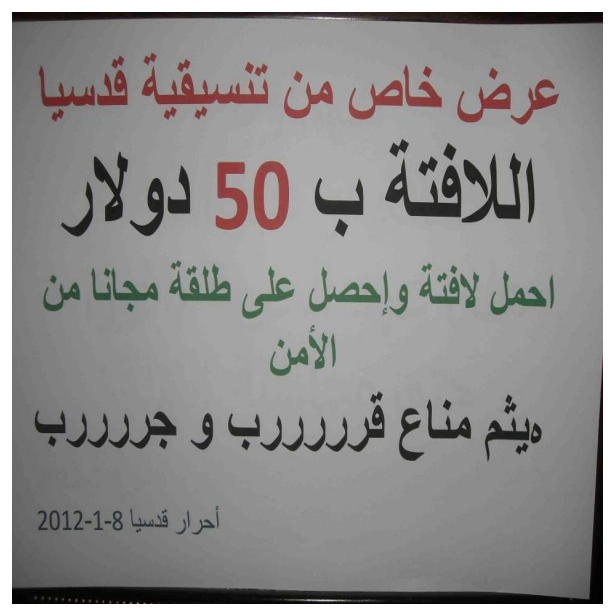

5.4.1

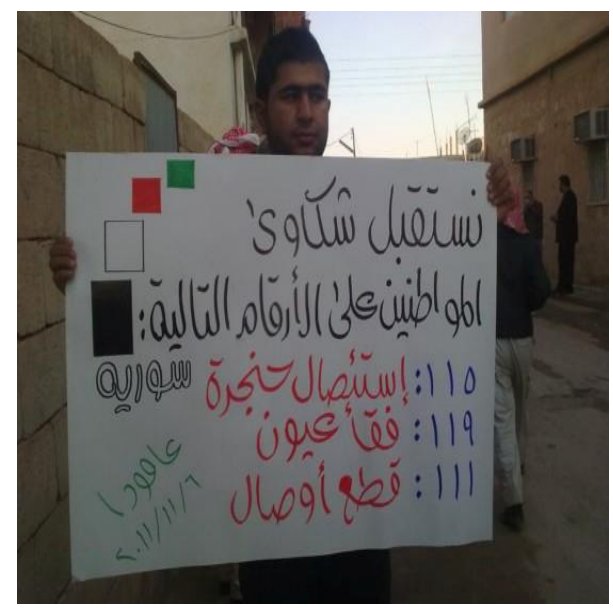

5.4 .2

Exposure of political repression is also portrayed in the following example where protestors are bombarded. The slogan wonders why Hems, a Syrian city is being bombarded alone while "Dara" another city is not though both cities have paid for buying the bombs.

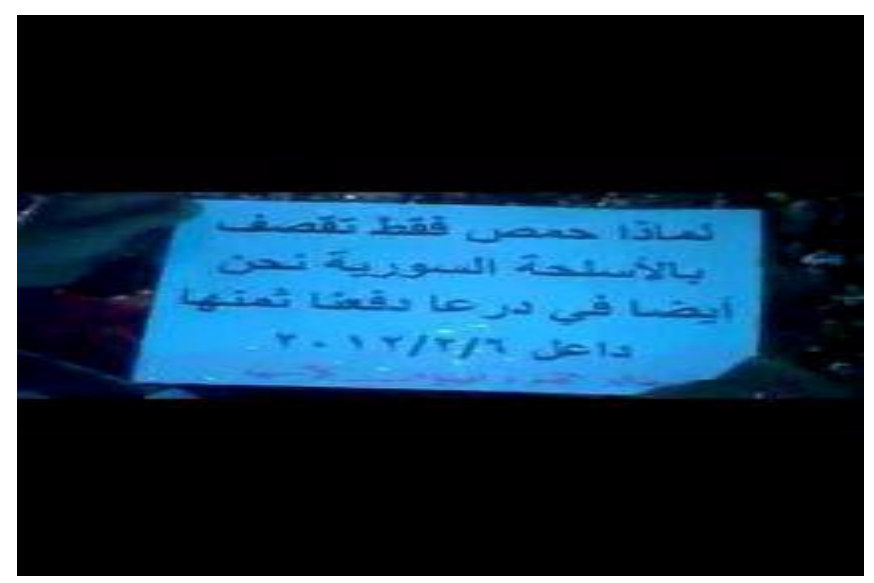

5.4 .3

Exposure jokes also involve exposure of shortages as illustrated by the following examples, the first portrays the drawbacks of Bin Ali, the Tunisian president, summarized in a form of a school certificate with low results in the subjects of freedom, justice, rights, development and excellent achievements as far as corruption and dictatorship are concerned. Finally the certificate ends with the expression, "expelled". The slogan in the middle is a school certificate for Mubarak in which he fails all subjects while the results for Bin Ali, the Yemeni president is full marks in injustice, ignorance, bribe, poverty and corruption concluding with a pass result and "to be moved to Jeddah". 


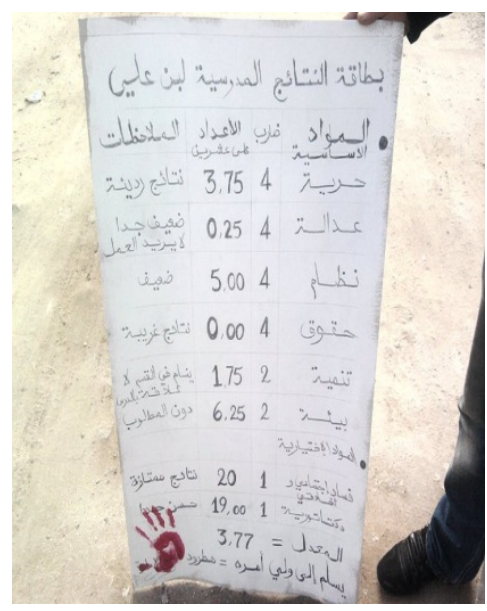

5.4 .4

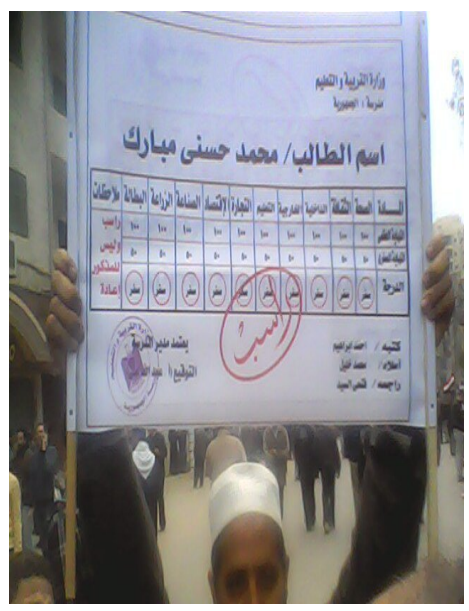

5.4 .5

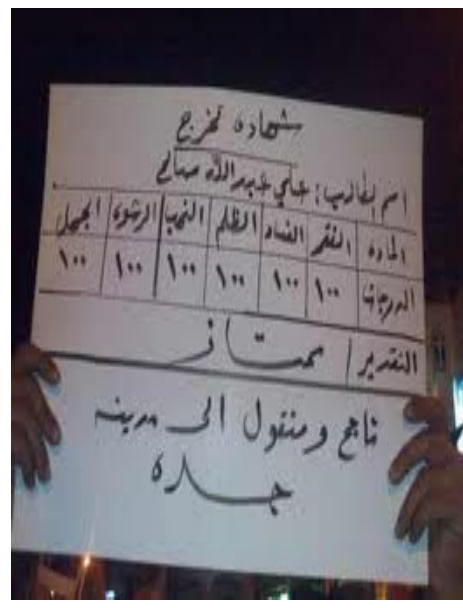

5.4 .6

Humor in exposure jokes derives as well from exposing a specific political situation as portrayed in the following example which comments on the political situation in Egypt after the rebellion of 25th January. The slogan provides a summary of the achievements of this rebellion which includes the resignation of the Jordanian government, emergency law in Algeria, amendment of the Chinese constitution, Yemeni and Iraqi presidents declaring that they would not run for new elections and suppressing the Syrians before they even thought to rebel. The slogan ends with "Hoping that that guy 'Mubarak' understands, Amen."

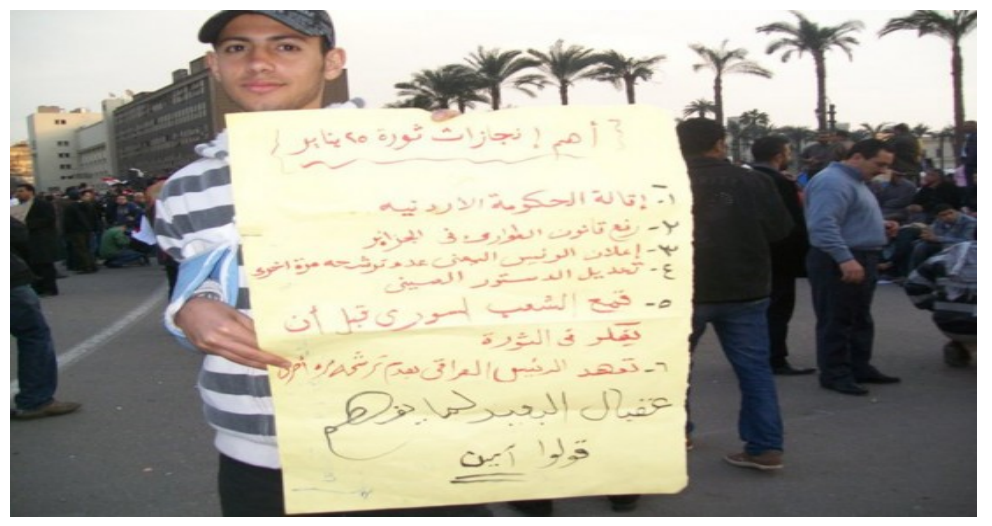

5.4 .7

\subsection{Intertextuality}

Intertextuality involves a text's interactions with prior texts, writers, readers, and conventions. Thibault (1994, p.175) explains this perspective stating: "all texts, spoken and written, are constructed and have the meanings which text-users assign to them in and through their relations with other texts in some social formation".

This term is coined by Kristeva on the basis of Bakhtin's work (Kristeva, 1986). Bakhtin (1986) argues that every text (or utterance) is dialogical, in the sense that it gains its meaning in relation to other texts. Kristeva (1981, p. 36) points out that a given text is "a permutation of texts, intertextuality: in the space of a given text, several utterances, taken from other texts, intersect and neutralize one other".

This section provides examples of the sources of intertextuality in slogans raised in some of the Arab Spring countries. 


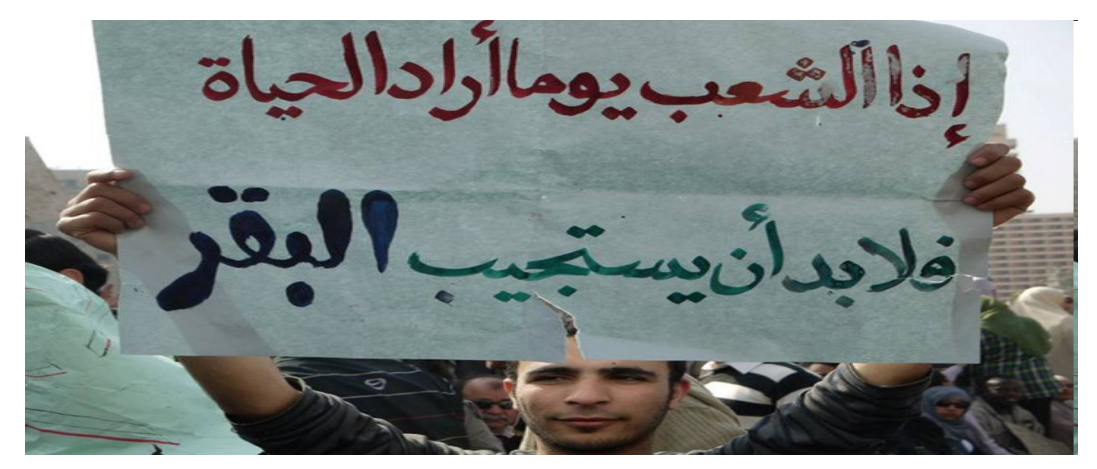

5.5 .1

Intertextuality in the example above derives from quoting one of the most famous poems by the Tunisian poet Abu Elqasem al-Shabi that talks about the fight for freedom and the necessity of achieving victory at the end. The first line is left as it is "If one day the nation decides to live". The second line "Then fate will for sure respond" is replaced by "then the cows will for sure respond". The word "cows" is used here to refer to Mubarak.

Intertextuality is also employed to scorn Mubarak in the following example where a name of a film is quoted but the basic title is replaced. The slogan literally means "Mubarak challenges boredom" alluding to that comic character in the movie.

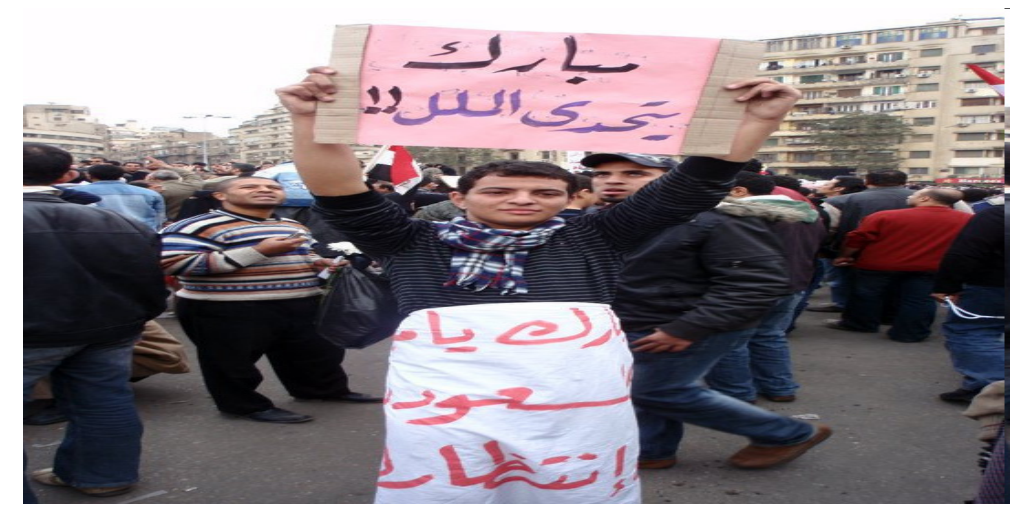

5.5 .2

Alluding to proverbs is also another source of intertextuality as is shown by the following example which reads "Me and my brother against my cousin, me and my cousin against the stranger, and me and the stranger against Asad"

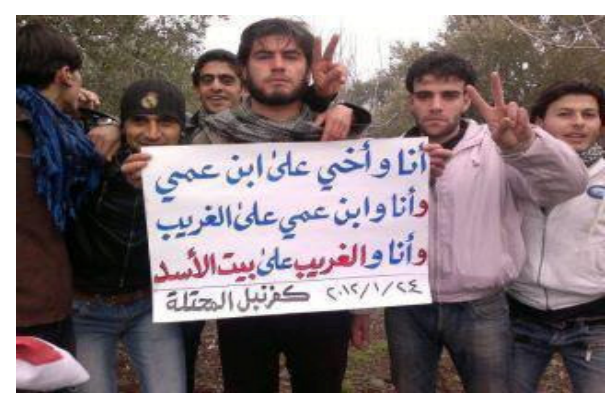

5.5.3 
An allusion to songs is obvious in the following examples. The first one is addressed to Asad quoting from a song telling him that all the roads in front of him are blocked. Example (5.5.5) mocks Asad by quoting from a song, the quoted lines say "He asked: Are you wise, he replied no, he asked: will you leave?, he said, no".

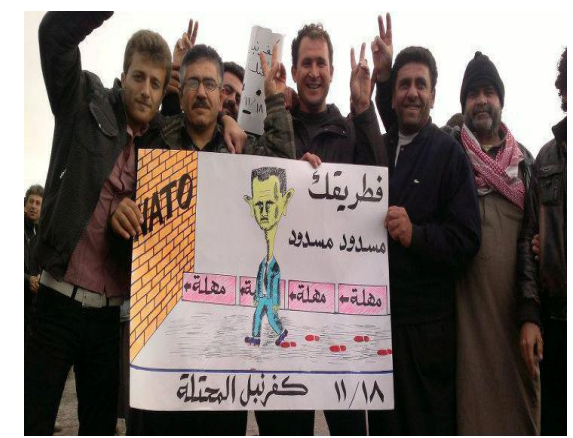

5.5 .4

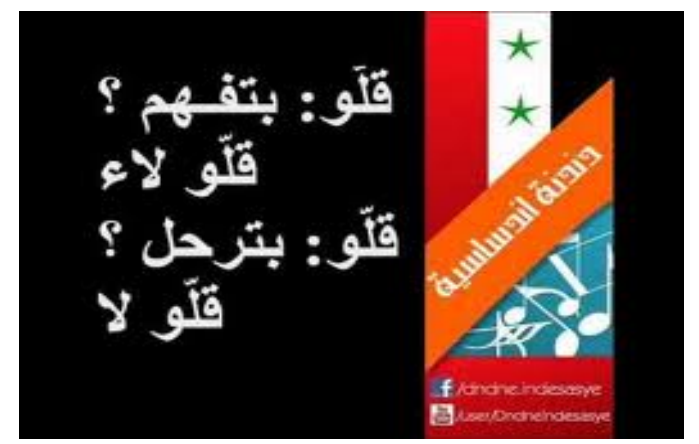

5.5 .5

In the following example, two sources of intertextuality are employed. In the first line there is a quote from a song, "What can we say, all is said".

The second line is alluding to Tefal product, "We need to bring Mubarak a Tefal chair", the implicature here is Mubarak is glued to the presidency chair and is unwilling to leave, the suggestion of replacing this chair by a Tefal one might help Egyptians get rid of him.

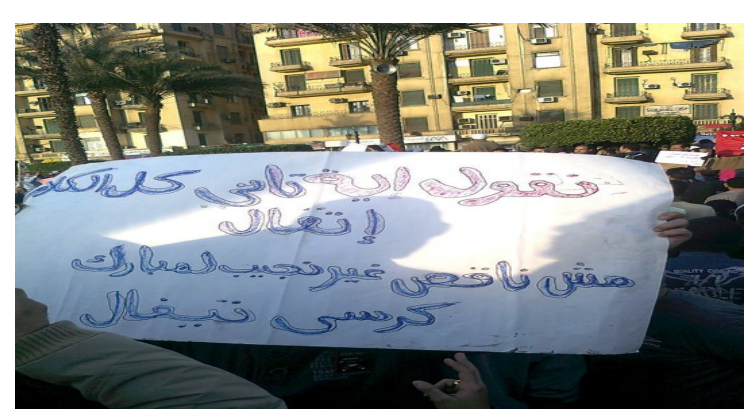

5.5.6

Another source for intertextuality was ads and commercials. In the following example, humor results from copying some ads and replacing product names by presidents' names. The following slogan provides a special offer for the Saudi king to receive Alqathafi and get Ben Ali for free.

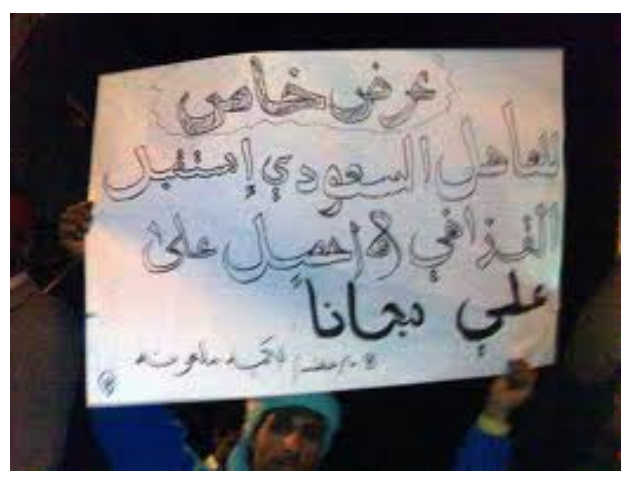

5.5.7 


\subsection{Linguistic Devices}

This section discusses some of the linguistic devices used to produce humorous expressions. In the following examples, the pun is used to create humor where the Arabic word "خلح" which could mean extract a tooth or remove Mubarak from power. The first example reads "A dentist, I came to extract Mubarak" while 5.6.2 reads "The nations' hospital, extracting a tooth 25 Bounds", extracting Mubarak $25^{\text {th }}$ of January.

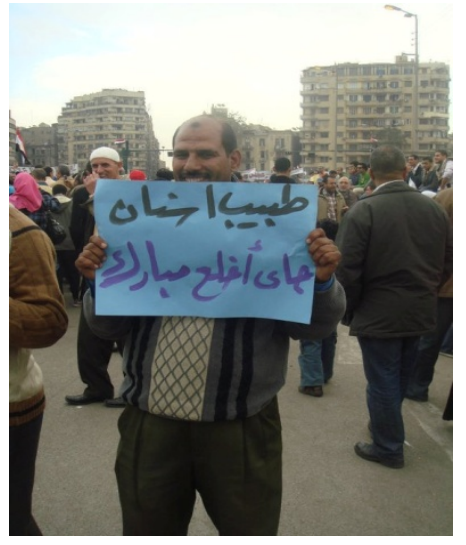

5.6 .1

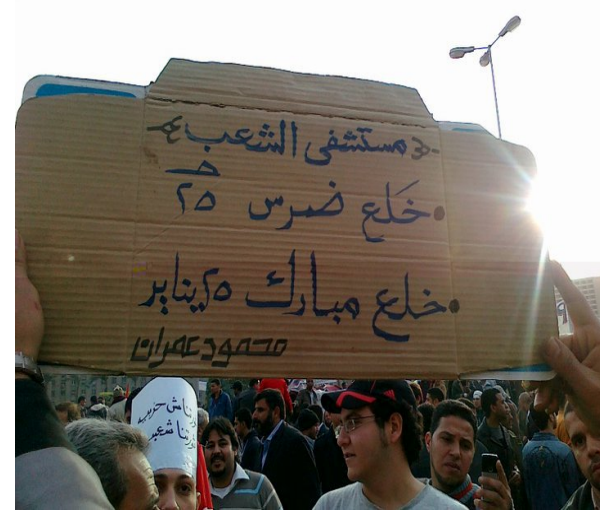

5.6 .2

In the following examples, the pun is used to refer to the Sudanese diplomate appointed by the Arab League as head of mission observers in Syria "Aldabi" whose name rhymes with "aldabehh" which means anything you can ride, basically animals. In (5.6.3) the Arabs are asked to ride "Aladabbi" and go back while in (5.6.4) pun is accompanied by intertextuality alluding to signs of the judgment day using the exact term " signs of "Aامات الساعة "Al the hour, one of these signs in the slogan is the appearance of "Al-dabi".

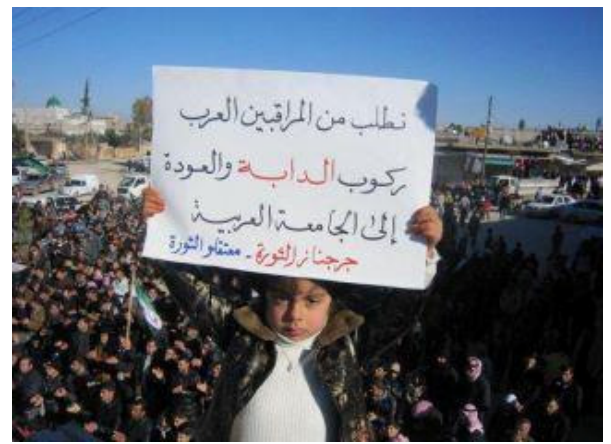

5.6 .3

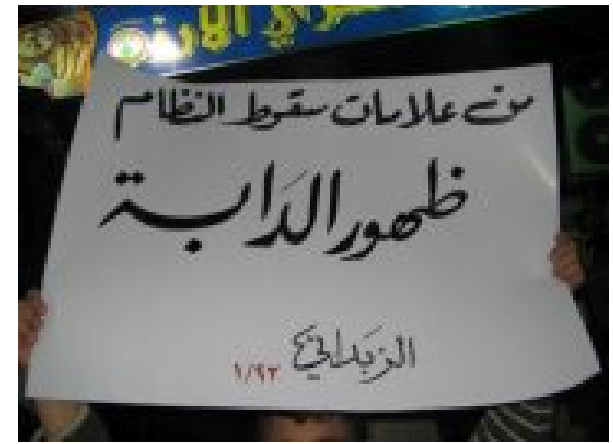

5.6 .4

In the following example, the pun is used to denigrate Asad's relative, whose name means "lion". The slogan reads "Dear Ref'at Asad, regarding your desire to be a president, do you think the presidential palace is a zoo?"

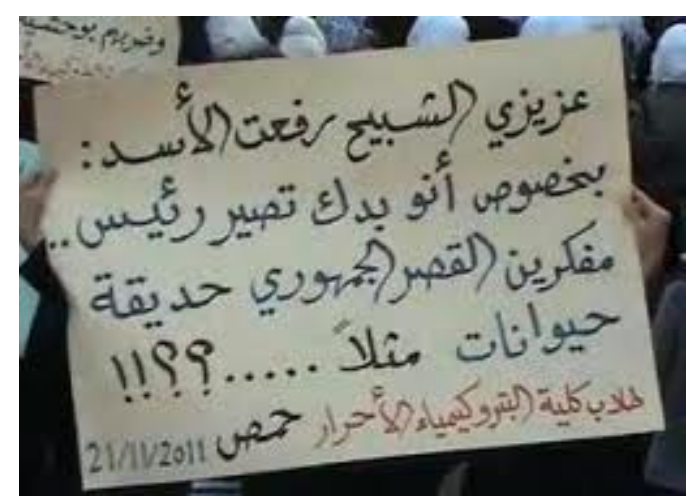


Antonymy is employed in the following instances to create humor which derives from the use of the word "start" and its antonym "stop". The slogan reads "Shooting stopped and bombarding started."

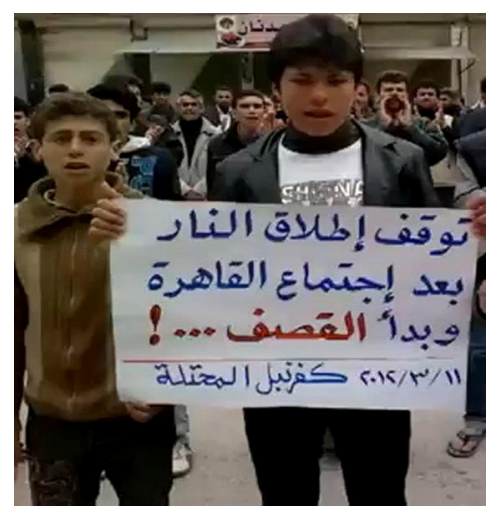

5.6 .6

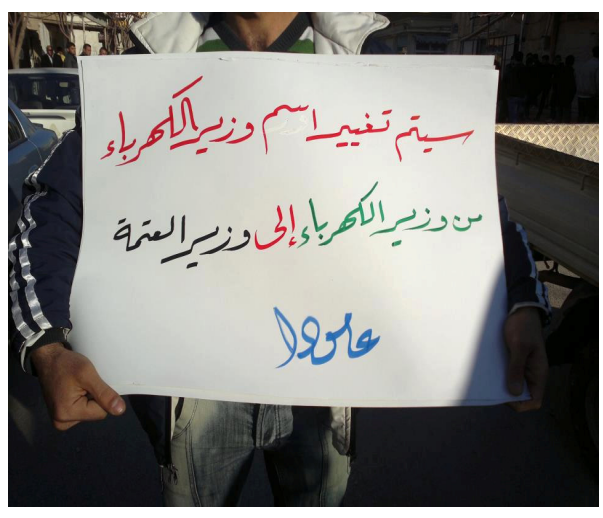

5.6 .7

In (5.6.7), the slogan reads: “The title 'minister of electricity' will be changed to 'Minister of darkness"'. In the following example, synonymy is used as a linguistic device where the three synonyms for the word "leave are given.

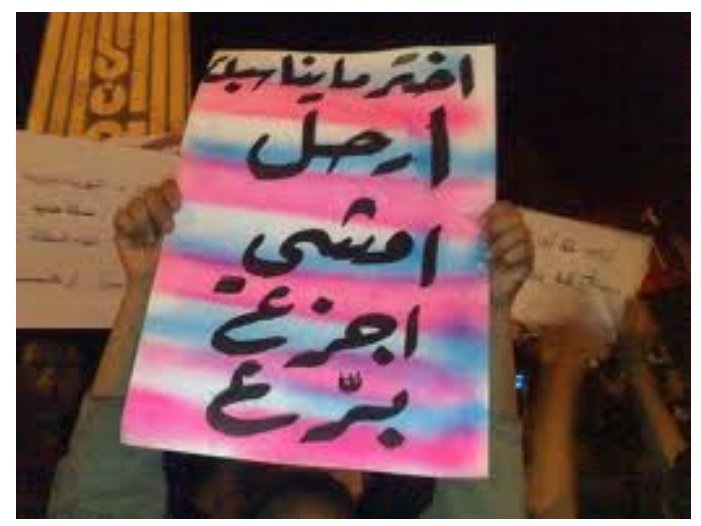

5.6 .8

Repetition was also employed to create humor as illustrated by the following examples. In (5.6.9), the word "مراقب" "observer" is repeated with its derivations. The slogan reads, "We ask for observers to observe the observers while they are observing". Example (5.6.10) utilizes repetition of the word "يهرب" "smuggle". The slogan reads, "Wanted: A Smuggler to smuggle the Yemeni president to Arabia" the second one next to it says, "leave Ali, here is the smuggler number".

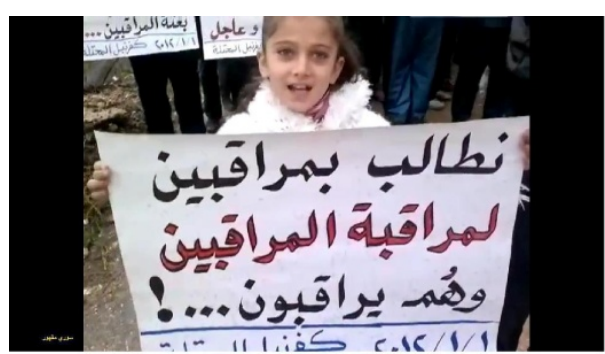

5.6.9

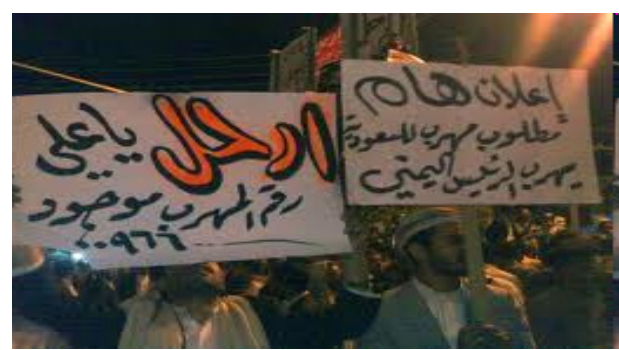

5.6 .10

Ambiguity is used for various functions in both spoken and written discourse. It has been used in the Arab Spring for various goals among which was to contribute to the humor of the message. In example (5.6.11) lexical 
ambiguity is employed to offend Mubarak by informing him that he is out of credit. This phrase could apply to his mobile or to his popularity among his people. In (5.6.12) lexical ambiguity is employed to demonstrate the brutality of the situation. The slogan reads, "Hims isn't bleeding, it is donating blood for those who have no blood". The expression "لمن ليس له دم", "for those who have no blood" means those in need of blood and those who are inconsiderate and bold.

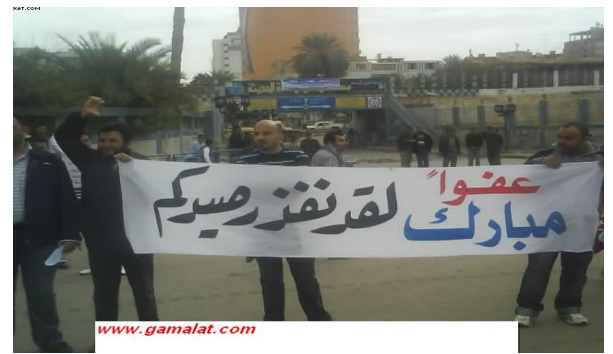

5.6 .11

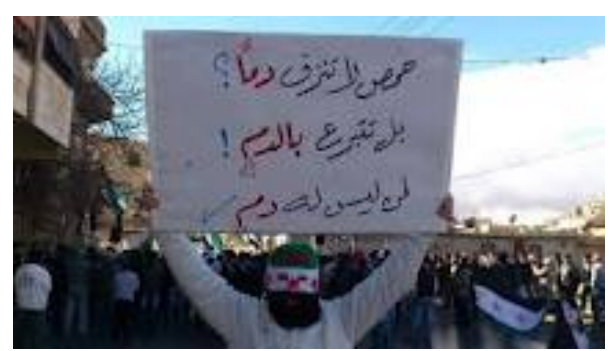

5.6 .12

Rhyme was another linguistic device that was utilized to add humorous effects to the slogans. In example (5.6.13) Mubarak is addressed "abu 'ala?" because the name ends with a glottal stop that rhymes with the rest of the words that all end in glottal stop. The slogan reads, "Oh, Allah, remove high prices, disease, and Abu Alaa". Rhyme is also used in the second example, the word, "hasri" rhymes with "masri". The slogan reads, "Lies are exclusive to the Egyptian TV."

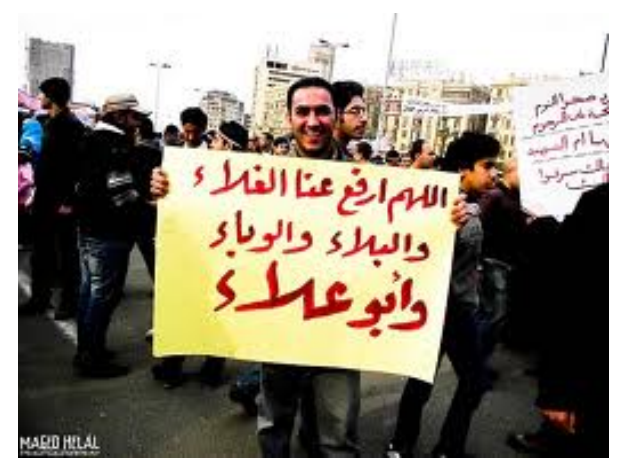

5.6 .13

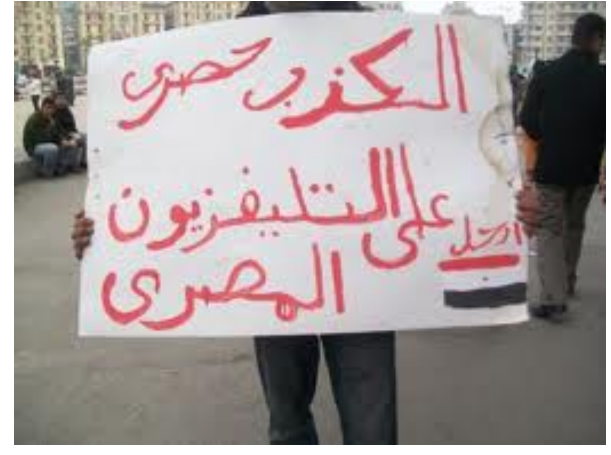

5.6 .14

\section{Conclusion}

The present study investigated the use of humor in four Arab Spring countries that included Egypt, Tunisia, Syria, and Yemen. Humor was classified according to Raskin's (1985) model. Intertextuality and linguistic devices involved were also identified. The study revealed that humor was used in the Arab Spring to denigrate the presidents of these countries. Sources for intertextuality included proverbs, songs, poetry and commercials. Humor made use of some linguistic devices such as puns, synonyms, antonyms, lexical ambiguity and rhyme. Further research is recommended to investigate sources of humor in oral jokes in Arab Spring countries.

\section{References}

Abu, H. W. (2013). Arab Spring Presidential Speeches and New Social Identities: A Critical Discourse Analysis Study. Proceedings of the European Conference on Arts \& Humanities. UK: Brighton.

Attardo, S. (1994). Linguistic Theories of Humour [Humour Research 1]. Berlin/NewYork: Mouton de Gruyter.

Attardo, S. (2001). Humorous Texts: A Semantic and Pragmatic Analysis [Humour Research 6]. Berlin/New York: Mouton de Gruyter. http://dx.doi.org/10.1515/9783110887969

Attardo, S., \& Raskin, V. (1991). Script theory Revis (it) Ed: joke similarity and joke representation model. HUMOR: International Journal of Humor Research, 4(3/4), 293-347. http://dx.doi.org/10.1515/humr.1991.4.3-4.293

Bergson, H. (1900/1911). Laughter: An Essay on the Meaning of the Comic. London: Macmillan. 
Billig, M. (2005). Laughter and Ridicule: Towards a Social Critique of Humour [Theory, Cultureand Society]. London: Sage.

Bippus, A. M. (2003). Humor motives, qualities and reactions in recalled conflict episodes. Western Journal of Communication, 67, 413-426. http://dx.doi.org/10.1080/10570310309374781

Bremmer, J. (1997). Jokes, jokers and jokebooks in Ancient Greek culture. In J. Bremmer \& H. Roodenburg, (Eds.), A Cultural History of Humor (pp. 11-28). Malden, MA: Blackwell Publishers.

Dailey, O. W., Hinck, A. E., \& Hinck S. S. (2005). Audience perceptions of politeness and advocacy skills in the 2000 and 2004 presidential debates. Argumentation and Advocacy, 41(4), 196-210.

Eco, U. (1986). The comic and the rule. In Travels in Hyperreality. New York: Harcourt Brace.

Fein, S., George, R. G., \& Matthew, B. K. (2007). Social influence on political judgments: The case of $\begin{array}{llll}\text { presidential debates. } & \text { Political } & \text { Psychology, } & \text { 28(2), }\end{array}$ http://dx.doi.org/10.1111/j.1467-9221.2007.00561.x

Freud, S. (1905/1991). Jokes and their relation to the unconscious (trans. A. Richards). London: Penguin.

Greimas, A. J. (1983 [1966]). Structural Semantics: An Attempt at a Method (trans. Daniele McDowell, Ronald Schleifer, \& Alan Velie, Lincoln). Nebraska: University of Nebraska Press.

Greimas, A. J. (1987 [1970]). On Meaning (trans. Frank Collins and Paul Perron). Minneapolis: University of Minnesota Press.

Keith-Spiegel, P. (1972). Early conceptions of humour: Varieties and issues. In J. Goldstein \& P. McGhee (Eds.), The Psychology of Humour (pp. 3-39). New York: Academic Press. http://dx.doi.org/10.1016/B978-0-12-288950-9.50007-9

Koestler, A. (1964). The Act of Creation (p. 38). New York: Penguin Books.

LaFollette, H., \& Shanks, N. (1993). Belief and the basis of humor. American Philosophical Quarterly, 30, 329-339.

Lahlali, M. (2011). The Arab Spring and the discourse of desperation: shifting from an authoritarian discourse into a "democratic" one. Journal of Arab Media and Society, 13.

Morreall, J. (1983). Taking Laughter Seriously. Albany: State University of New York Press.

Morreall, J. (1987). The Philosophy of Laughter and Humour. Albany, NY: State University of New York Press.

Mulkay, M. (1988). On humour: its nature and its place in modern society. Cambridge, UK Oxford, UK New York, NY, USA: Polity Press B. Blackwell.

Piddington, R. (1933). Psychological Aspects of Culture Contact. Oceania, 3, 312-324. http://dx.doi.org/10.1002/j.1834-4461.1933.tb00076.x

Powell, C., \& George, E. P. (1988Humour). Humour in Society: Resistance and Control. London: McMillan. http://dx.doi.org/10.1007/978-1-349-19193-2

Provine, R. R. (2000). Laughter: A Scientific Investigation. New York: Viking.

Raskin, V. (1985). Semantic Mechanisms of Humor. Dordrecht \& Boston \& Lancaster: D. Reidel Publishing Company.

Raskin, V. (1985). Semantic Mechanisms of Humour [Studies in Linguistics and Philosophy y24]. Dordrecht: D. Reidel.

Rhodes, T. (2013). Protests in a New Perspective: A Discourse Analysis on the Arab Spring APSA 2013 Annual Meeting Paper American Political Science Association 2013 Annual Meeting. Retrieved from http://papers.ssrn.com/sol3/papers.cfm?abstract_id=2302074 on 201212014.

Sacks, H. (1972). An Initial Investigation of the Usability of Conversational Data for Doing Sociology. In D. Sudnow (Ed.), Studies in Social Interaction (pp. 31-74). New York: Free Press.

Sherzer, J. (1978). Oh! That's a pun and I didn't mean it. Semiotica, 22(3/4), 335-350. http://dx.doi.org/10.1515/semi.1978.22.3-4.335

Vaid, J. (1999). The evolution of humor: do those who laugh last? In D. H. Rosen \& M. C. Luebbert (Eds.), Evolution of the Psyche (pp. 123-138). Westport, Connecticut: Praeger Publishers. 


\section{Copyrights}

Copyright for this article is retained by the author(s), with first publication rights granted to the journal.

This is an open-access article distributed under the terms and conditions of the Creative Commons Attribution license (http://creativecommons.org/licenses/by/3.0/). 